\title{
THE HOUSING AUTHORITY AND THE HOUSED
}

\author{
Charles S. Ascher*
}

Housing under public auspices raises some new problems in the relationship between the housing authority and the housed, which lead to a critical examination of the traditional legal devices for stating their reciprocal rights and duties. Up to the present the owner and occupier, the buyer and seller, the mortgagee and mortgagor, have dealt at arm's length as parties adverse in interest: their relationships have been basically financial. The legal instruments drafted by the attorneys for the dominant financial interests have recited endless covenants by the tenant-buyermortgagor, many of which the depression has shown to be of little real value to the interests sought to be protected. Conveyancers, of all lawyers, have been the most direct lineal descendants of the medieval schoolmen: their concepts have been least related to the economic and social problems with which they had to deal.

Now comes the "service state"-an organization developed largely in the last century-and broadens its attempt to use taxation and the police power to malie available to the underprivileged those advantages deemed socially essential, which the current economic system does not afford them. To schools, preventive health work, public recreation (an activity of the last twenty-five years) and adult education (even more recent); to water, sewers, light, gas, crime prevention, fire prevention, the state now adds housing as a public facility. What legal devices will best provide a frame-work for this activity?

The first distinction between public housing and most commercial private housing for low-income families is the continuing interest of the state in the housed. We may expect here standards of production for use, not for profit; of design to meet basic needs, not to attract by insubstantial, flashy gew-gaws; and as a corollary a lasting interest in the well-being of the occupants. (This interest is just as "paternalistic" as a pre-natal clinic or supervised playground.) It is not unfair to say that the commercial builder's interest is to get out from under as quickly as possible; it is enlightened self-interest only which dictates whatever concern he shows with the oceupier. The dwelling should be substantial enough to last as long as the mortgage.

Continuing interest involves continuing control. This is the first reason why the

- A.B., I920, LL.B., r92x, Columbia. Member of New York and Illinois Bars. Executive Director, National Association of Housing Officials; Secretary, Public Administration Clearing House, of Chicago. For five years attorney for City Housing Corporation, of New York, the limited-dividend corporation which built Sunnyside Gardens, Long Island, and Radburn, New Jersey. 
method of sale and mortgage (or purchase contract, or bond for a deed) is poorly suited to the needs of public low-cost housing. The seller's only controls are those of conditions or restrictive covenants in the deed, or covenants or conditions in the purchase-money mortgage. These are precarious devices. Conditions in a deed, leading to a forfeiture for violation, are so drastic that they are frowned upon in many states. They amount practically to a cloud on title, since it is impossible to establish by the record that they have not been violated. Even where the forfeiture is enforcible, the confiscation of the buyer's economic interest is grossly unfair.

The remedy for a violation of a restrictive covenant is a chancery suit for injunction to prevent the violation or enforce compliance with the terms of the deed. This is not a tool capable of fine adjustment. It is difficult to obtain a preliminary injunction pending the determination of the issue, which may take a year. The burden of money and time in pursuing such an action falls upon the other grantees. And the familiar maxim of equity requires an affirmative showing that an injunction will benefit the complainant more than it harms the defendant. A busy chancery court might be convinced if the defendant had built a wall blocking a neighbor's light; but hardly if the defendant kept his grounds untidily, or if his wife persistently hung the wash in the front lawn. ${ }^{1}$ In short, the restrictive covenant is a legal, not an administrative device. It has nothing to do with low-cost housing.

Covenants or conditions in the purchase-money mortgage are equally unhandy as a method of control. Legitimately they can relate only to matters affecting the financial security of the mortgagee. Their enforcement is so painful and expensive that even in case of serious default, mortgagees will go to any length to avoid foreclosure. Costs of foreclosure searches, advertising charges, referee's and auctioneer's or sheriff's fees, the uncertainty caused by redemption periods, all eat up the mortgagor's equity without benefitting the mortgagee.

More fundamentally, I do not believe that low-cost housing for sale is economically sound. This, I know, is a discord in the harmony woven around the little gray home in the west, bulwarks against bolshevism, and sound citizenship. I take it that one of the objectives of public low-cost housing is social distribution of the risk. The long-term purchase agreement, by which the prospective buyer puts up a small initial payment and pays the rest like rent, works just the opposite effect. There is no real prospect of profit in a stabilized venture (though the purchaser may be deluded into imagining that some day he can sell his plot for an apartment-site); and the "ownership" which follows his fractional economic interest in the property throws on him the risk of losing all his investment in case of slight misadventure, like any other margin trader. If, as in a time of extensive inflation, there seems to be a profit, I see no justice in letting it all go to the party who invested least.

\footnotetext{
${ }^{1}$ See Ascher, The Enforcement of Deed Restrictions (1932) 8 Ciry Planning 193; Monchow, Thr Use of Deed Restrictions in Subdivision Development, Chicago: Institute of Land Economics, 1932. But see Parsons v. Duryea, 26I Mass. 314, 158 N. E. 76I (1927).
} 
This is the final break-down in any attempt to control property which has been sold: no satisfactory scheme has been evolved for controlling re-sale. Any forthright provision will generally be held to be in valid as a restraint on alienation. ${ }^{2}$ An agreement not to resell without first offering the property to the grantor is valid, but not useful. It is exhausted by a single offer which is refused; and the offer will often come at time when grantor does not want to repurchase. ${ }^{3}$

The chief arguments for the sale of low-cost housing are that saving is stimulated. Land economists have a phrase for it: they speak of the "ladder" from tenancy to ownership. Furthermore, the purchaser can use his own labor as a substitute for services which must otherwise be bought and paid for in rent: he can be his own janitor and repair man. The argument based on pride in home-ownership impresses me less since Viennese workers recently defended their rented premises to the death.

A word should be said about coöperative ownership. In some European countries the bulk of low-cost housing has been built by governmental financial aid to great coöperative building societies. It would be going too far afield to explore the reasons why we have not a substantial tradition of coöperative enterprise in this country. Experience to-day warrants the conclusion that low-cost coöperative housing is likely to succeed only if the occupants have some other cohesive bond: being members of a minority race, of a trade-union, or of a nationality (like the Finns or Scandinavians) to whom the scheme is familiar. Other wage-earners seem hopelessly confused by the indicia of their interest-a stock certificate evidencing proprietorship, and a lease evidencing the right to possession; and so long as we have a free labor market and extreme mobility of population, the departing coöperator will find it hard to cash in on his investment when he most needs to.

Finally, the management of real property calls for definite skills and experience which not every wage-earner under our technological tenuity (page Stuart Chase) may be assumed to have; and there are genuine economies to be achieved by mass operations. Utility services and fuel can be supplied at wholesale; the enterprise can afford the overhead expense of competent managers.

This analysis leads me to believe that something nearer the landlord-tenant relationship will best serve public low-cost housing. Control is certainly easier. I have not canvassed the laws of the forty-eight states, but it must be the exceptional jurisdiction where a landlord has not some comparatively summary remedy to regain possession for default in a covenant in a lease. I set aside the drastic rent lien which

\footnotetext{
${ }^{2}$ Restrictive covenants against resale to classes of persons-Negroes, Asiatics-are enforcible in some states, not in others. And of course, restrictive covenants, for what they are worth, can be made to "run with the land" and bind subsequent purchasers. The artificialities surrounding this principle would do credit to Duns Scotus.

${ }^{3} \mathrm{Cf}$. the option to repurchase in the event of the violation of stipulations concerning use contained in the option agreement. This device, the cmployment of which by the Public Works Administration is described by Blucher, supra at p....., must run the gauntlet of the rule against perpetuities and, where the option-holder is also mortgagee, the rule against elogring the equity of redemption. Its validity is as yet untestcd.
} 
is still allowed in some states; ${ }^{4}$ it is a barbarous medieval relic and rendered ineffective for low-cost housing in jurisdictions where there is an exemption of a minimum amount of property.

Under continued public ownership, the risk is distributed socially as widely as possible. If the project has been constructed at a time of low cost, rents need never be raised above a sum sufficient to cover operating expenses and the retirement of financial obligations. If the project is built at high cost levels, the rents may have to come down to meet the competition of other rents; but in that case, it will not be the occupier who bears the major burden of loss. The advantages of mass operation will be available. (I shall say something later about promoting good citizenship.)

Yet, though this be the basic pattern, I doubt whether the lease, as it has been used in the past, will be broad enough to encompass all the relationships of housing authority and housed. Perhaps it can be expanded; but what is needed is more of an administrative than conveyancing frame-work.

First of all, few wage-earners sign leases at all. Most low-rent tenancies are month-to-month; and the law has sanctioned these informal relationships by building around them a body of doctrine. Somewhat greater formality must undoubtedly attend a letting by a public body; but I shall be surprised if low-wage-earners are persuaded to sign leases that look like an insurance policy, printed in six-point type. I note that many of the laws authorizing the creation of public housing agencies provide that they may establish by-laws, rules and regulations governing the conduct of their affairs. ${ }^{4}$ There are interesting administrative possibilities in the use of this device. What significance will the courts give to the regulations of what is in effect a municipal corporation? To what extent will they be binding on occupiers, and by what means will the courts enforce them?

This striving to find sanctions beyond the confines of a lease arises again out of the problems of parens patria as landlord. If the Zilches are unsatisfactory tenants, the private property owner either puts up with them till the lease is out and then refuses to renew-passing the problem of unassimilated Zilches on to other landlords, and what is worse, to other suffering fellow-tenants. Or he tries to establish in court that they are undesirable, and splits his occupants into warring camps: the Kettles, who come to testify that Johnny Zilch breaks milk bottles in the yard, that Cora Zilch pulled their daughter's hair, or that Mr. and Mrs. Zilch had loud words at midnight when he came home drunk; versus the Potts, who join with the Zilches in calling Mr. and Mrs. Kettle and all the little Kettles black. Even if the judge decides in favor of the landlord, and the Zilches move out, the Kettles and Potts will glare

\footnotetext{
'Foreman, Rent Liens and Public Welfare (i932).

4 A law enacted by the Kentucky legislature in the regular session of 1934 (House Bill 585) provides for municipal housing commissions, to be an arm of the city government, like a park board, sewerage commission, or schonl board. The law authorizes the commission to adopt by-laws, rules and regulations, and empowers the city council by ordinance to provide penalties for their violation.
} 
at each other in the hallways, and loudly instruct their children not to play with those dirty brats, the little Potts and Kettles. ${ }^{5}$

If Johnny Zilch is a problem child, that is no responsibility of the private landlord. If Johnny's problems find overt release, the landlord may turn Johnny over to the juvenile court. But the city's interest is basically different. It cannot divorce so completely its responsibility as landlord and its obligation as re-moulder. of delinquent children. Indeed, is not the almost inevitable preliminary to a public housing program the spot map blanketing areas of bad housing with cases of crime, disease, delinquency, desertion, and other municipally expensive social ills?

Consider the case of the tenant who commits the gravest sin of all, failure to pay rent. Even the most sympathetic judge can only shake his head sadly, and explain regretfully that he must decide for the landlord. What is worse, even the sympathetic landlord cannot let the non-paying tenant stay on. He tells the truth when he says that he cannot act as a relief agency: we have seen enough landlords on the relief rolls themselves.

The municipal landlord, on the other hand, can invoke all the machinery of employment services and public assistance before the family is thrown on the street. It would be intolerably artificial rigidly to separate these public functions, and to accept the four corners of a lease as the limits of the reciprocal duties of the parties. ${ }^{b}$

As both public housing abroad and a few private large-scale demonstrations here have shown, low-cost housing projects of the type now proposed are more than the provision of cheap shelter, they presage a new mode of life. Community laundries, organized adult education and recreation, forums, libraries, pre-school child training and care, consumers' coöperatives for the purchase of food and household supplies, are but examples of the new relationships not only between landlord and tenant, but between fellow-tenants which the housing program involves. The child clinic and dental clinic which are already in the picture may even be the forerunner of socialized medicine.

How are these activities to be reflected in the rent structure? What journal entries shall we make on our municipal books? Are the welfare, recreation, education, library, and health departments, out of their budgets, to provide workers and equipment to carry on these activities in public housing projects? Or shall the housing authority, if an independent body, or the municipal housing department, attempt to collect, as rent, some or all of these costs, to reimburse the other divisions of the government? I have to pose these as a series of questions, because there are yet no answers. The solution will vary from place to place and time to time. If there is a library in the housing project (or a clinic, or playground or school) shall it serve

\footnotetext{
'See Ascher, Some Reflections on the Art of Administering Deed Restrictions (1932), 8 Joun. of Land Econ., 373-377.

'I know of one private large-scale landlord, the Bridgeport Homes Company, of which Mr. William Ham has been the manager since the War, which took affirmative steps during the depression to find sources of income for its unemployed tenants, by developing the manufacture of markctable arts and crafts products by them.
} 
only the tenants of the city, or also less fortunate neighbors, still dwelling in slums irridenti? $^{7}$ One of the merits claimed for a project in Cleveland is that a large community center already exists across the street, and therefore there will be no capital cost to the project for the provision of these facilities. How should this affect the rents?

Public housing presents still another possibility for adjusting the charge for shelter upon social considerations. This is the policy called in England "differential rent," already in vogue in twenty-four cities. It is expounded briefly in the appendix by Mrs. Eva M. Hubback to Sir Ernest Simon's "The Anti-Slum Campaign."8

It is an attempt to give regard to need as well as ability to pay, by basing the rent upon the size of the family. The low wage earning couple with many children are not to be penalized for needing many rooms, but are to pay a proportionately diminished rent for each additional child. The city of Leeds is reported to have carried this principle even further:

A tenant with more than a certain family income will pay the full economic rent of his home-that is, whatever would be the rent of the house if there were no subsidy payable in respect of it. The subsidies so released will be pooled, and from the pool rebates of rent will be made to poorer tenants, until a man with an income below a certain point will pay no rent at all. ${ }^{9}$

The problem of tenant selection will perhaps raise legal questions: it will certainly raise administrative ones. The state has already taken a hand here in New York by making it a penal offense for a private landlord to refuse to rent an apartment because the prospective tenant has children. ${ }^{10}$ Of course, only a stupid landlord will run afoul of this expression of legislative moral fervor; with only slight ingenuity he can think of enough other excuses to make it impossible to secure a conviction. There is really a series of problems here. Can a means test be invoked? Until our cities suffer a more general transformation than will result from the first demonstration projects, it will be true that however simple the dwellings, the standards of light, air, and amenity resulting from the low land coverage and provision of community facilities will produce an environment pleasanter than that in which most urban readers of this journal now live: the intelligentsia will crowd hard on the proletariat.

What evidence of assimilability can be required from prospective residents? If our old friends, the Zilches, have a long record in the welfare agencies, domestic relations court and juvenile court, or have a feeble-minded child with perverse tendencies, can they safely be counted on to take part in a scheme of living which

'Cf. the simation in Simon v. O'Toole, ro8 N. J. L. 549, 158 Atl. 543 (1932); aff' $g$, on opinion below, 108 N. J. L. 32, 155 Atl. 449 ( 1931 ). There the City of Newark was sustained in spending $\$ 1,200,000$ to buy as a playground the inner portion of a block around the perimeter of which a limited-dividend corporation had built a housing project. The city's agreement to purchase stipulated that the playground was "to be maintained by the city for the benefit of the public at large."

- Simon, The Anti-Sium Campaign (1933).

- Manchester Guardian, Weckly Edition, February 9, 1934, p. I.

${ }^{20}$ N. Y. Cons. Laws (Cahill, 1930) c. 41, 520.4I. 
calls for active, creative coöperation with neighbors? This question is not intended to suggest for a moment that I share the Tory notion that slum-dwellers cause slums: there is plenty of evidence that any normal family will rise to a better opportunity, sometimes with tears of joy. I am thinking rather of socially pathological cases that may disrupt a promising experiment in community organization. ${ }^{11}$

And then there is a problem which must gravely concern those who are responsible for framing the administrative schemes for public housing. We have heard from Herr Dollfuss's sympathizers that the Viennese housing projects were "Socialist fortresses." Public housing had been provided for perhaps 250,00n wage earners (in a city of $1,750,000$ ) by a Socialist administration. Are our American projects to become Democratic fortresses? Sir Raymund Unwin reports that in English cities there are a number of election districts in which a majority of the voters now live in municipally owned dwellings. Picture a municipal campaign waged on competing platforms for the reduction of the rents of the public housing! A free radio in every apartment!

Ultimately, of course, the problem is one of building an administrative ésprit that scorns such considerations; but the pattern can promote or retard the growth of this delicate plant. It seems almost essential to interpose some administrative agency between the electors and the elected, which will not be too sensitive to the winds of political change. A housing board with overlapping terms (whether a part of the city government, or an independent authority) seems essential; with freedom to pick its personnel on merit (whether or not under civil service).

I have been able in this brief article only to suggest those inadequacies for public housing which we already recognize in our time-honored legal doctrines of relationship between houser and housed; and to pose some questions which are already in prospect, before the first public housing project is completed. I cannot answer all these questions: it will take the best skills and creative imagination of lawyers and administrators during the next few years to answer them. The answers will vary; meantime new questions will arise out of actual experience. Those in the field have a right to look to persons like the readers of this journal for help.

${ }^{11}$ At Hilversum, Holland, a separate housing project was provided for non-coopperators, from which they were allowed to graduate when they showed enough social education to take their place in a decently coöperative environment. See Housing: The Need, Fortune, Feb. 1932, p. 92. 